\title{
The contribution of geomorphological mapping to sediment transfer evaluation in small alpine catchments
}

\author{
David Theler ${ }^{\mathrm{a}, *}$, Emmanuel Reynard ${ }^{\mathrm{a}}$, Christophe Lambiel ${ }^{\mathrm{a}}$, Eric Bardou ${ }^{\mathrm{b}}$ \\ a Institute of Geography, University of Lausanne, Anthropole, CH-1015 Lausanne, Switzerland \\ ${ }^{\mathrm{b}}$ Research center on alpine environment (Crealp), rue de l'Industrie 45, CH-1950 Sion, Switzerland
}

\section{A R T I C L E I N F O}

Article history:

Received 11 May 2009

Received in revised form 23 February 2010

Accepted 2 March 2010

Available online 12 March 2010

\section{Keywords:}

Geomorphological mapping

Sediment transfer

Sediment storage

Debris flow

Swiss Alps

\begin{abstract}
A B S T R A C T
The assessment of sediment transfer processes is necessary to understand the hydro-geomorphological functioning of small alpine watersheds prone to channelised debris flows because their occurrence often depends on the amount of debris available in the gully systems. Therefore, sediment budgets should be studied through the identification of erosion, transport and deposition processes. Sediment transfer processes were investigated in a small catchment by field measurements and, more specifically, through the application of a process-based geomorphological mapping method. The proposed methodology is based on data directly derived from GIS analysis using high-resolution DEM, field measurements and aerial photograph interpretations. It has been conceived to estimate sediment transfer dynamics, taking into account the role of different sediment stores in the torrential system. The proposed geomorphological mapping methodology is quite innovative in comparison with most legend systems that are not adequate for mapping comprehensively active and complex geomorphological systems such as debris-flow catchments. Maps representing the various sediment storages and their relationships can be used for hydro-geomorphological hazard mitigation.
\end{abstract}

(c) 2010 Elsevier B.V. All rights reserved.

\section{Introduction}

Debris flows are one of the most important vectors of sediment transfer in mountainous areas (Sterling and Slaymaker, 2007) and they often occur in small alpine torrential catchments. Their hydrogeomorphological behaviour is conditioned by geological, geomorphological, topographical, hydrological, climatic and anthropic factors. European research in torrential systems has focused more on hydrological processes (e.g. magnitude-frequency analyses, Zimmermann et al., 1997; Hungr et al., 2008) than on geomorphological processes acting as debris flow triggers (Johnson and Warburton, 2002, 2006).

Nevertheless, the identification of sediment volumes that have the potential to be mobilised in small torrential systems, as well as the recognition of processes responsible for their mobilisation and transfer within the torrential system, are important in terms of land-use planning and natural hazard management. Since the end of the Little Ice Age, the lower part of most torrential systems in the Alps has been channelised and human infrastructures and buildings have intensively occupied the alluvial fans developed at their mouth. The vulnerability of such human settlements may be quite high even if intensive control measurements are applied as dams, dykes, reforestation (e.g. Gutiérrez et al., 1998).

\footnotetext{
* Corresponding author.

E-mail address: david.theler@unil.ch (D. Theler).
}

A correlation between rainfall and debris-flow occurrence is not always established and a number of debris flows seems to occur when a poorly understood geomorphological threshold is reached (Bovis and Jakob, 1999; Sterling and Slaymaker, 2007). This fact reveals the high uncertainty when modelling this kind of system, called by Stiny (1910) "weathering" or "supply-limited systems", which are characterised by sediment transport directly depending on the amount of debris available in the main channel. This kind of system is common in the Alps (Veyrat-Charvillon, 2005).

The estimation of sediment volumes that have the potential to be mobilised and transported by debris flows has been studied with the concept of "sediment cascades" that allows the calculation of sediment budgets of several subsystems of the whole torrential system (Barsch and Caine, 1984; Schrott et al. 2002, 2003; Otto and Dikau, 2004; Becht et al., 2005). According to Reid and Dunne (1996) and Beylich and Warburton (2007), the calculation of a sediment budget necessitates the identification of the processes of erosion, transportation and deposition acting within the catchment, and assessing their rates and controls. Moreover, the identification of the main sediment storages is essential for conceptualising torrential systems as a succession of connected reservoirs with variable storage periods and emptying velocities. In this context, geomorphological mapping may be a useful tool for characterizing the processes responsible for the formation of sediment stores in the upper part of the catchment.

This article presents a simple geomorphological method for mapping sediment storages that may constitute source zone of bed load transport and debris flows. It aims at identifying and mapping the 
deposits that may be mobilised during a hydro-meteorological event as a preliminary step before quantifying their volumes. The method, conceived mainly for small and steep catchments, is based on both field mapping and classical GIS tools applied to high accuracy DEMs. The proposed approach applies the concept of "sediment cascade" in a cartographic point of view. It focuses especially on short-term processes (e.g. channel recharging) acting as debris flow triggers. The mapping method and preliminary results obtained for the Bruchi torrent (Western Swiss Alps) are presented and discussed in this paper.

\section{Developing a dynamic geomorphological mapping method}

\subsection{Scientific background}

Geomorphological mapping is a classical tool for representing the spatial distribution of landforms and processes. However, the classical methods suffer from a certain number of limitations. For instance, geomorphological mapping is time-consuming work that may be quite difficult in steep mountain areas and regions densely covered by vegetation (Kienholz 1978; Klimaszewski, 1982; Otto and Dikau, 2004; Van den Eeckhaut et al., 2004; Gustavsson et al., 2006, 2008; Van Asselen and Seijmonsbergen, 2006). In addition, geomorphological maps provide an instantaneous image of complex and dynamic geomorphological systems and may be affected by the subjectivity of the cartographer (Van Asselen and Seijmonsbergen, 2006). These are some of the reasons why the activity of geomorphologists in this domain has decreased since the end of the 1980s, after the very active 1960-1980 period when numerous mapping systems were developed and, sometimes, adopted at the official level. This decline coincides with the development of Geographical Information Systems (GIS) that allowed the development of new approaches to represent landforms (Vitek et al., 1996). Nevertheless, the combination of the two approaches (GIS and field mapping) is considered to have great potential in the analysis of complex systems and to be particularly appropriate to the study of active geomorphological systems (Gustavsson et al., 2006).

Classical geomorphological maps are generally insufficient to satisfactorily represent dynamic environments like torrential catchments, especially because their related landforms (natural levees, gullies, landslide features, etc.) may change very quickly over a short temporal and spatial scale (Bonnet-Staub, 2001; Bardou, 2002; Theler and Reynard, 2008). Moreover, on a large scale $(1: 10,000,1: 5000$ or higher), active processes increase the difficulty of precisely delineating landforms and distinguishing their erosional or depositional nature (Fig. 1). This distinction is, however, the basis of numerous geomorphological legends designed to produce the so-called morphogenetic maps, with significant limitations for process analysis, natural hazard prevention and land-use planning.

Tricart (1971) was one of the precursors who proposed a system representing geomorphological dynamics by mapping the susceptibility of slopes to erosion. The development of GIS, and especially the possibility of working with various layers of information (slope, aspect, lithology etc.), allows susceptibility maps to be produced quite quickly (e.g. Parise, 2001; Moreias, 2005; Fall et al., 2006; Kamp et al., 2008). Most of the research on susceptibility mapping of debris flows has been developed at a small scale (e.g. Latulippe and Peiry, 1996; BonnetStaub, 2001; Kneisel et al. 2007; Carrara et al., 2008) and have provided good results for identifying triggering sources of debris flows.

At a larger scale, Veyrat-Charvillon (2005) developed a procedure for mapping the intensity of sediment production based on the geological classification of terrains proposed by Marie (1992) and applicable in lithological contexts dominated by clays. Other authors (e.g. Pasuto and Soldati, 1999; May, 2008) used specific symbols to represent morphodynamic processes in geomorphological maps at various scales. From the point of view of susceptibility zonation, it is important that the resulting map contains the maximum information necessary for modelling debris-flow propagation, like the spatial distribution of sediment available.

In Switzerland, the "phenomena legend" (Kienholz and Krummenacher, 1995) used for susceptibility mapping provides a wide range of symbols aimed at representing the dynamics of processes. It must be redrawn after each new event and all the maps should finally be superposed to have a comprehensive view of the hazardous areas (Bardou, 2002; Theler et al. 2008). Bardou (2002) proposed adaptations of the legend by integrating a distinction between effective and potential sediment supply to a debris channel (Theler et al. 2007). Mapping sediment transfers in mountain watersheds necessitates identifying all the processes and landforms included in the erosiondeposition system, as well as their relationships. The combination of different processes, depending on the scale, may be very complex and difficult to map. As was proposed by Lee (2001), an approach combining GIS processing, field mapping and surveying is to be preferred. The proposed method follows such recommendation.

\subsection{Identification and mapping of sediment storages}

The proposed approach is organised in six steps (Fig. 1). The first stage consists in localizing potential sediment sources within the torrential system. This phase is based on the analysis of geomorphological features identifiable by means of aerial photograph interpretation, processing the Digital Elevation Model (DEM) and field survey. In theory, the supply area corresponds to the reception basin of the torrent. In practice, due to the strong heterogeneity of the slopes (Johnson and Warburton, 2002), some parts of the reception basin may be completely inactive, whereas supply zones may be identified along the transport channel, and even on the upper part of the alluvial fan.

A key issue is to determine if the sediment storages are connected or not with active channels and/or the main channel (step 2). This task is done by simulating the hydrographic network using classical ArcGIS $₫$ hydrologic tools on precise DEM (1-5 m of resolution), already in use for more than two decades (Mark, 1984; Vogt et al. 2003), and by means of field observations. Based on the assumption that sedimentary transfers correspond to hydrological fluxes, this step (step 3) allows areas that contribute runoff and sediments to a common outlet to be determined and permits the detection of secondary channels, their connection point with the main channel and the delineation of several subcatchments (Theler and Reynard, 2008; Theler et al., 2008). Drainage areas corresponding to preferential channels are then delineated after verification of the connection points in the field. The approach allows the delimitation of small geomorphological units in the same way as proposed by Pasuto and Soldati (1999) for landslides or by Bartsch et al. (2009) for periglacial processes. The properties of the subcatchments, which may be composed of various sediment storages, are then described and mapped (step 2).

\subsection{Mapping sediment storages as geomorphological units}

\subsubsection{Morphogenesis of sediment storages}

The geotechnical characteristics of non-consolidated deposits are a key element in the triggering process of debris flows (e.g. Sitar, 1994; Cannon and Reneau, 2000). Several authors (e.g. Sanchez, 2002; Otto, 2006) have proposed classifications of sediment storages. In this study, seven types of storages corresponding to seven groups of processes typical for alpine contexts were differentiated (glacial, fluvio-glacial, fluvial, gravitational, organic, structural and periglacial) and mapped in the fourth step. Glacial deposits may be dominated by sand, gravel and boulder fractions (lateral moraines) or by clays (lodgement till). Fluvio-glacial and fluvial sediments are generally quite porous, with a dominant gravel fraction. Talus slopes are dominated by gravel- and boulder-sized clasts of crystalline and limestone rocks, and may be quite cohesive and impervious where 


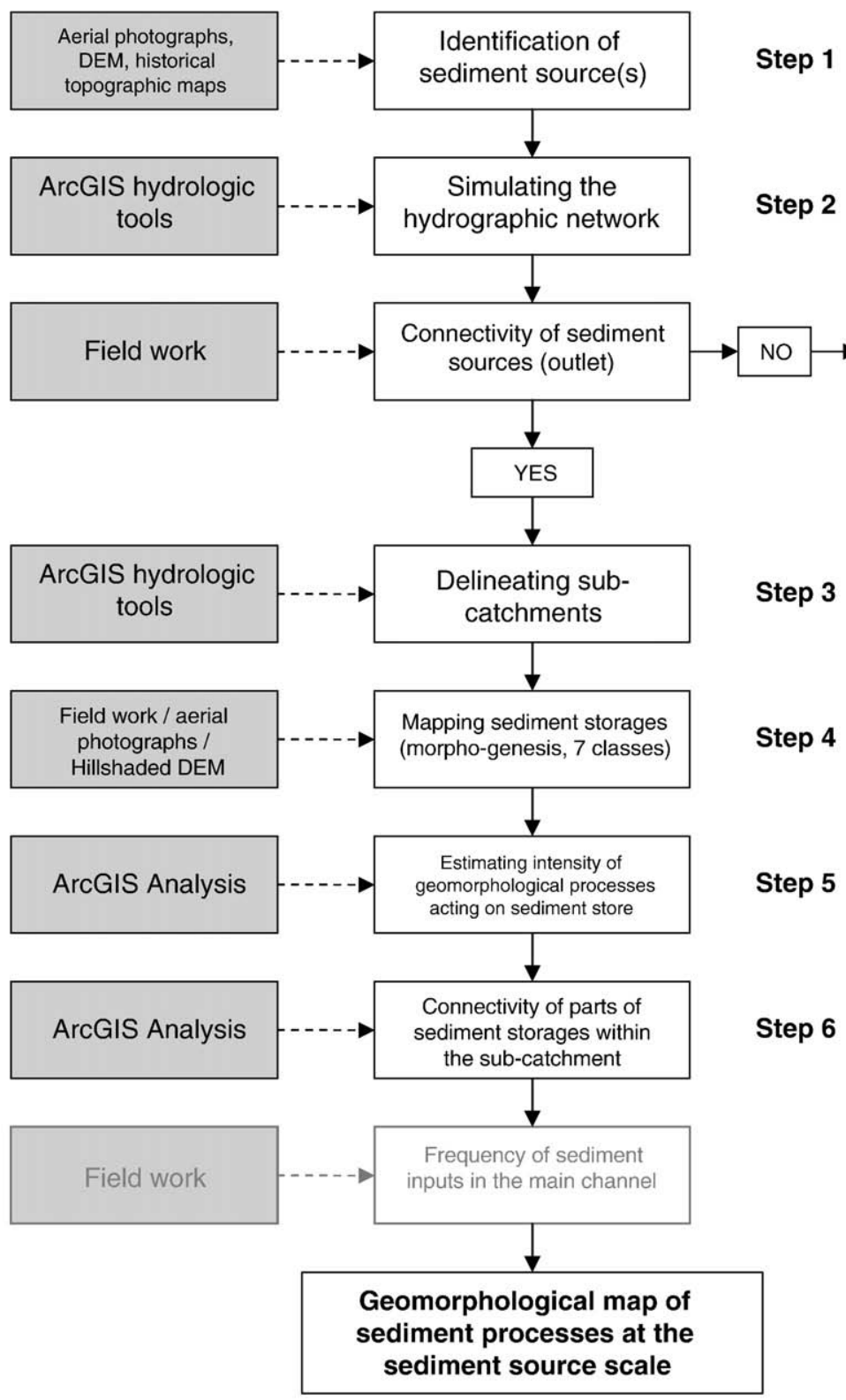

Fig. 1. Flow chart illustrating the procedure used in the presented mapping method for small alpine catchments.

derived from some fine-grained metamorphic and shale lithologies. We consider structural surfaces - i.e. free faces or rock escarpments on fractured or folded rocks - as storage surfaces, because they can have a quite similar behaviour to unconsolidated materials. Periglacial sediments are often cemented by seasonal or perennial ice (e.g. rock glaciers, frozen talus slopes or protalus ramparts). Although periglacial landforms are not present in the investigated site, some studies were conducted in other sites and more specifically on rock glaciers and other periglacial depositional landforms.

In morphogenetic mapping legends, processes are generally represented by different colours. In this study, we used a typical panel of colours in reference to principles established by Joly (1962) and adopted in the legend of Lausanne University (Schoeneich, 1993) that relate to different types of processes (glacial, periglacial, gravitational, fluvial, etc.) responsible for the accumulation.

\subsubsection{Activity of sediment storages}

According to Beylich and Warburton (2007), the storage is unstable when contemporary geomorphological processes frequently modify the sediment. Active sediment storages are devoid of any vegetation or lichens. Sediment storages are "semi-active" when they are only modified during events with a return period between 10 and 100 years and contain pioneer vegetation species. Sediment storages are considered stable when deposition processes are no longer active. These inactive sediment storages are covered by old vegetation (optimal or climatic level) and only extreme events (return period between 100 and 1000 years) can modify the deposit (high fluvial terraces, vegetated scree cones, Holocene moraines).

Each contributing zone (subcatchment) is mapped by using two simple matrixes (Fig. 1, step 5, Fig. 2) inspired by the legend for hazard mapping in Switzerland (OFAT et al., 1997). Four characteristics are described (slope, vegetation, connection with the main channel, and genetic processes responsible for the storage). The first matrix combines information on slope and vegetation cover, directly derived from the DEM, and allows zones that are sensitive to erosion to be distinguished. Three classes of intensity are derived (high, latent and inactive). The second matrix takes up the information of the first matrix (intensity of the process acting on depositional landform or 


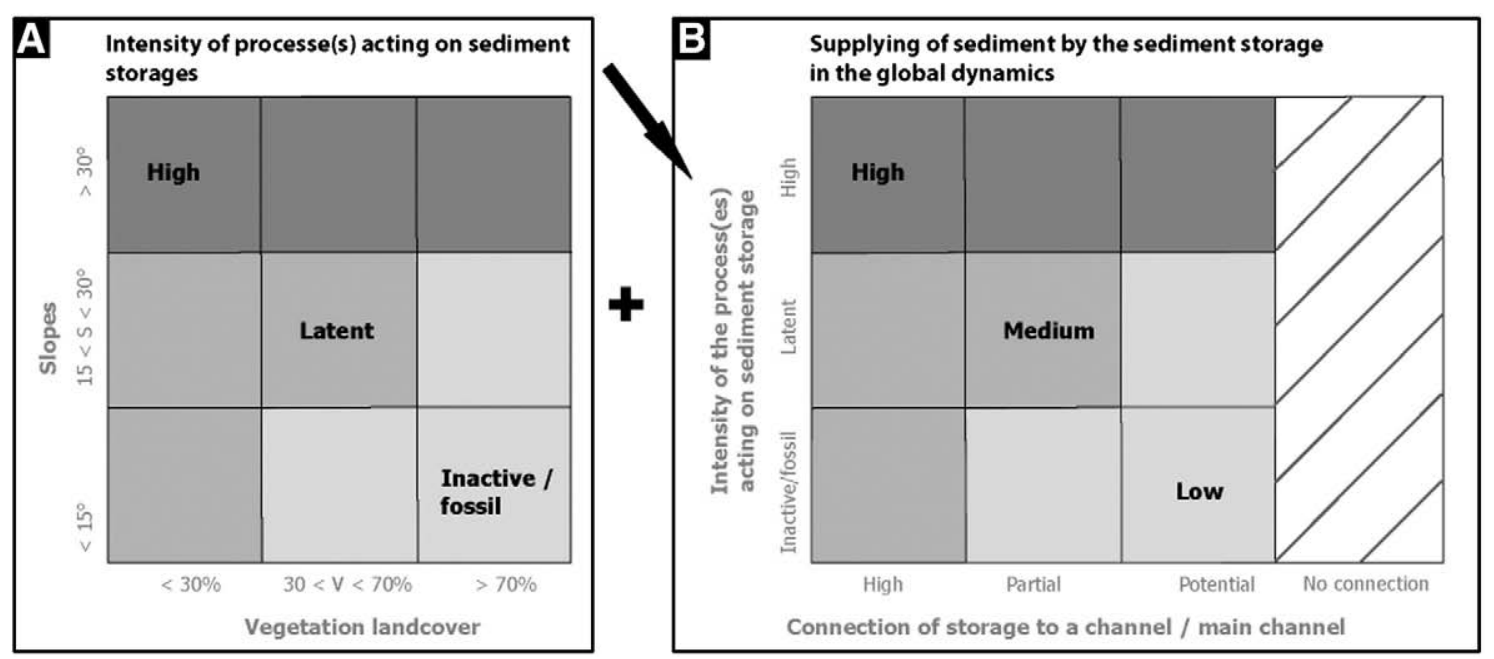

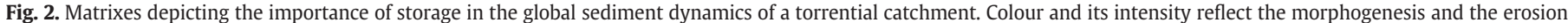
potential of sediment storages.

sediment storage) and crosses it with the connection of the storage with the main channel. This allows the role of the storage on sediment transfer to be defined in three classes (low, medium, and high). Homogeneous polygons within the different subcatchments composing the whole torrential system can then be determined by combining the two matrixes by spatial analysis in a Geographical Information System (GIS). Three colour intensity levels (shading) were used to depict the morphodynamics and, more specifically, the role of the storage in the global sediment dynamics of the sub-watershed.

2.3.2.1. Slope gradient. Information on slope gradient is essential in the creation of debris-flow susceptibility maps. According to BonnetStaub (2001), the minimal gradient for debris-flow initiation in slopes is $25^{\circ}$, and $11-12^{\circ}$ for remobilisation of sediments accumulated in the channels. In morainic deposits - more cohesive than other nonconsolidated sediments - the minimum triggering slope is comprised between 27 and $38^{\circ}$ for events launched by runoff concentration at the foot of hillslopes (Rickenmann, 1995). Based on these values, three classes of slope were defined $\left(<15^{\circ}, 15-30^{\circ},>30^{\circ}\right)$. These values corresponds to the average slope of fans $\left(<15^{\circ}\right)$ and the lower bound of the friction angle of scree deposits $\left(>30^{\circ}\right)$.

2.3.2.2. Vegetation. The role of vegetation in slope stability is variable but can be of a great importance (Greenway, 1987) by diminishing rain-drop impact and runoff and by stabilising non-consolidated sediments through the effect of the root system. Hence, vegetation may contribute to disconnect sediment transfer between upstream and downstream areas (Borselli et al., 2008). Generally, alpine watersheds span from densely forested areas to vegetation-free slopes and channels, passing through sparsely vegetated areas. The geomorphological activity of the catchment may be approached through the mapping of these vegetation units (e.g. Bardou et al., 2007).

The vegetation landcover can be mapped on the basis of aerial photographs or by using the differences of two high accuracy LiDAR (Light Detection And Ranging) airborne DEMs (Gachet, 2009); one replicating the land surface with soil cover, vegetation and buildings, and the other showing gross topography. In this study, we combined the first approach and the second option by using two DEMs provided by the Swiss topographical survey (the so-called MNS - surface elevation model - and MNO - ground topography model, see Theler and Reynard, 2008). The precision is about $\pm 150 \mathrm{~cm}$ for the first model and $\pm 50 \mathrm{~cm}$ for the second one, with a density of points of $1 /$ $\mathrm{m}^{2}$ (Swisstopo, 2007). By spatial analyses, three classes of landcover (>70\%, 30-70\%, and $<30 \%$ ) were defined. These density ranges were proposed by Veyrat-Charvillon and Mémier (2006), who considered the works conducted in different lithological contexts by Rogers and Schumm (1991), Mc Ivor et al. (1995) and Rey et al. (2004). The type of vegetation is important too; bushes and trees have varying root depths and also provide varying loading on the slope. These parameters were considered implicitly in the landcover classification.

\subsubsection{Connectivity}

Sediment connectivity was recently studied by Heckmann et al. (2009) and Borselli et al. (2008), who developed two connectivity indices based on a GIS and raster-based approach and on field survey, respectively. The connectivity of the sediment sources with the main channel has a relevant importance in the evaluation of the volume of sediments potentially mobilised during a debris-flow event (Zimmermann et al., 1997) and is often correlated with the hydrological connectivity (Croke et al., 2005; Borselli et al., 2008; Michaelides and Chappell, 2008). According to Hooke (2003) and Croke et al. (2005), the sediment connectivity may be direct, through secondary gullies and new gullies created during an event, or diffuse, through surface runoff. Connectivity defines a system in which coarse particles move easily and frequently through the system, transported by 'normal' flood events, i.e. with recurrence intervals of ca. $0.5-5$ years. The analysis of the connectivity allows the selection of the geomorphological units that may feed directly the main channel (step 6). Four classes of connection (high, partial, potential, and no connection) were defined. Only the first three are used in mapping sediment storages. High connectivity indicates that the sediment storage is directly connected to the main channel. The connectivity is considered "partial" when the stored material is partially connected to the channel, for instance, because of low slope angle. The connection is potential when it has not yet been established but could be achieved through the modification of the current topography. Finally, no sign of connectivity is indicated when the connection between the unit and the main channel has not been established. However, this situation is likely to evolve over the short to medium term, depending on the geomorphological changes that could occur in the system. In our situation, certain zones are "not connected" due to large levees (Fig. 4G) that prevent the sediment transfer from reaching the main channel.

Although the interfluves contribute also to the sediment supply, the processes involved, mainly mass movements and superficial runoff, do not have a strong influence in the sediment dynamics of the Bruchi torrent. Thus, we consider that they can be neglected at this scale and for this case study, although landslides may be sometimes an important triggering factor of debris flows (e.g. Gabbet and Mudd, 2006). 


\subsubsection{Symbology}

Specific symbols adapted to small torrential watersheds were created. They integrate generic hydrographical elements (lakes, springs), artificial structures that may disturb the flow (bridges, hydropower infrastructures as dams), as well as dead wood debris accumulations that may have a high impact on flow by damming the channel, increasing sedimentation upslope, and developing pendant bars downstream of the log accumulation due to flow dissipation when the obstacle does not occupy the whole river bed (Maridet et al., 1996). However, damming by vegetation debris may also have positive impacts by limiting the sediment transfers and reducing the hydraulic energy.

The activity of the process acting on the sediment store is represented by an arrow, whose size is proportional to the intensity/ frequency of the process involved. The principal processes acting in the transfer of sediments from the stores to the main channel are the fall of individual blocks from the scarped channel margins, gullying, talus creation and channel deepening and widening by the main flow (Veyrat-Charvillon, 2005).

\section{Example of application in the Bruchi torrent}

\subsection{Geomorphological setting}

The method was applied in the Bruchi torrent, a complex torrential system in the Swiss Alps. This perennial watercourse $(7.5 \mathrm{~km}$ in length) constitutes the main tributary of the Kelchbach torrent, which flows from the west of the Massa River basin. Its source is situated at about $2800 \mathrm{~m}$ a.s.l., in a depression located at the foot of the Hohstock Mountain (3226 m) (Fig. 4). The upper part of the stream is characterised by a meandering channel that flows through pastures developed on granitic and gneissic rocks of the Aar Massif (Steck, 1966) on which "roches moutonnées" have been sculptured by glaciers. The complex configuration of the drainage network near Belalp is related to infiltration feeding springs that are situated in the Bruchi catchment downwards. These underground flows increase the weathering of the gneisses. Moreover, gullies occur in slopes characterised by mass movements fostering gneiss erosion and rockfalls. The summit of the catchment is located at $2000 \mathrm{~m}$ a.s.l. which is well below the lower limit of discontinuous permafrost.

Traditional geomorphological mapping with the geomorphological legend of the University of Lausanne (Schoeneich, 1993) conducted on the whole valley and analysis of geomorphological features using a high accuracy DEM, allowed us to map the geomorphology of the area (Theler et al., 2008; Fig. 3), which is typical of an alpine valley shaped by glaciers. The Aletsch Glacier, the largest glacier in the alpine range, deposited erratic boulders and well preserved moraine ridges, like the lateral Late-glacial moraine of Egga village. The retreat of the Aletsch Glacier involved debuttressing in the oversteepened slopes, triggering rockslides and landslides as in most formerly glaciated alpine valleys. These movements affect particularly a slope located near the village of Tchuggen. The slope shows large gullies inherited from geomorphological processes more active in the past, after deglaciation. Erosion processes were then dominated by watercourses like the Massa River, which incised deep gorges downstream from the Gebidem dam, or by snow avalanches that transport periodically rocky debris to the Kelchbach River. Slope gradient ruptures down from high glacial escarpments, corresponding to the Last Glacial Maximum trimline, accelerated regressive erosion and provoked intensive gullying by small and temporary watercourses whose bed load transport capacity may be high (Theler and Reynard, 2008).

\subsection{General overview}

In the Bruchi torrent, the largest part of the sediment load is transported periodically by channelised debris flows and comes from a large gully system (gulling zone) west of Egga settlement (1600-
$2000 \mathrm{~m}$ a.s.l, "GZ" in the geomorphological map). This situation is not typical of torrential systems where the erosion zone, from which most of the sediment load is derived, is situated in the upper part of the system. The gullying zone $\left(4.2 \mathrm{~km}^{2}\right)$ is very active and the perimeter evolved rapidly between 1940 and 1999 (Bollschweiler, 2003), especially near the Blatten-Tschuggen-Belalp road, where regressive erosion has reached about $70 \mathrm{~m}$ in 30 years (Theler and Reynard, 2008). Debris flows developed in this unstable zone have built a large alluvial fan above the Blatten settlement and sometimes passed through the small Blindtälli valley, where old inactive channels and frontal lobes are still visible. Dendrogeomorphological analyses (Bollschweiler et al., 2007) and mapping of 53 natural levees and 164 debris flow lobes in the alluvial fan, allowed the reconstitution of more than 40 debris flow events between 1867 and 2005. Eleven channels that were active in the past were identified (Bollschweiler et al., 2007). To prevent damage, protection measures were applied in the 1970s including the construction of a dam and a retention basin, and the reinforcement of the sides of the main channel. After the event of 4 July 2001, the dam and the retention basin had to be reinforced, and new embankment works began at the alluvial fan apex in the summer of 2008.

\subsubsection{Sediment storages}

The geomorphic activity varies spatially as illustrated in Fig. 4. In the upper part of the main gully system (GZ), talus accumulation due to gelifraction processes acting on the subvertical cliffs is dominant, as revealed by the sharp shape and the fresh appearance of the rock fragments visible in the channels. Some clasts are stored temporarily at the foot of the cliffs as thin debris accumulations. Localised small rockslides $\left(<100 \mathrm{~m}^{2}\right)$ are also visible in the north-eastern part of the gullying zone. In the north-western side of the gully system, material is transported and accumulated preferentially by fluvial processes in a network of secondary gullies that are active only during severe rainfall events. Downvalley, the sediment transport is higher and follows a well-defined network of lateral channels whose functioning is similar to a small hydrological catchment. Those main potential sediment sources are described below.

Important stocks of older fluvial sediments corresponding to levees (sediment store No 10 in Fig. 4) and covering the bank are also visible along the main channel of the Bruchi torrent. The absence of trees and lichens shows that the store is unstable and is affected by erosion processes during flow events. Downstream, the banks have been reinforced by ripraps but they show abundant evidence of erosion and destabilisation, which is a supplementary indication of the high erosional activity along the main channel.

Two geomorphological units (respectively in the right and left sides of the Bruchi channel, 1 and 3 in Fig. 4) correspond to a landslide affected by shallow debris slides. This is a complex case for several reasons. Landslides are a major source of sediments in numerous torrential systems and the spatial and temporal variability of their activity is difficult to estimate (Korup, 2004; Mathys and Poesen, 2005; Schuerch et al., 2006). Landslides situated near the watercourses interact with the flow by increasing the sediment load or by forming an obstacle to the water circulation (Schuerch et al., 2006), and even by favouring large debris-flow events (Malet et al., 2005). The volumes involved can vary radically from one landslide to another, and also seasonally, with the maximum mobilised volumes generally in spring and winter (Schuerch et al., 2006). In our case, the sediment supply is mainly due to regular shallow debris slides occurring at the surface of the landslide that turn into debris flows. The contribution of debris flows depends on the situation of the supply zone with respect to the main channel. Here the gullies are perpendicular to the main channel. The mobilisation of sediment occurs in two phases; debris flows accumulate deposits near the main channel, and this material is then mobilised during larger flow events. Geomorphological units 7 and 8 (on Fig. 4) were difficult to reach in 


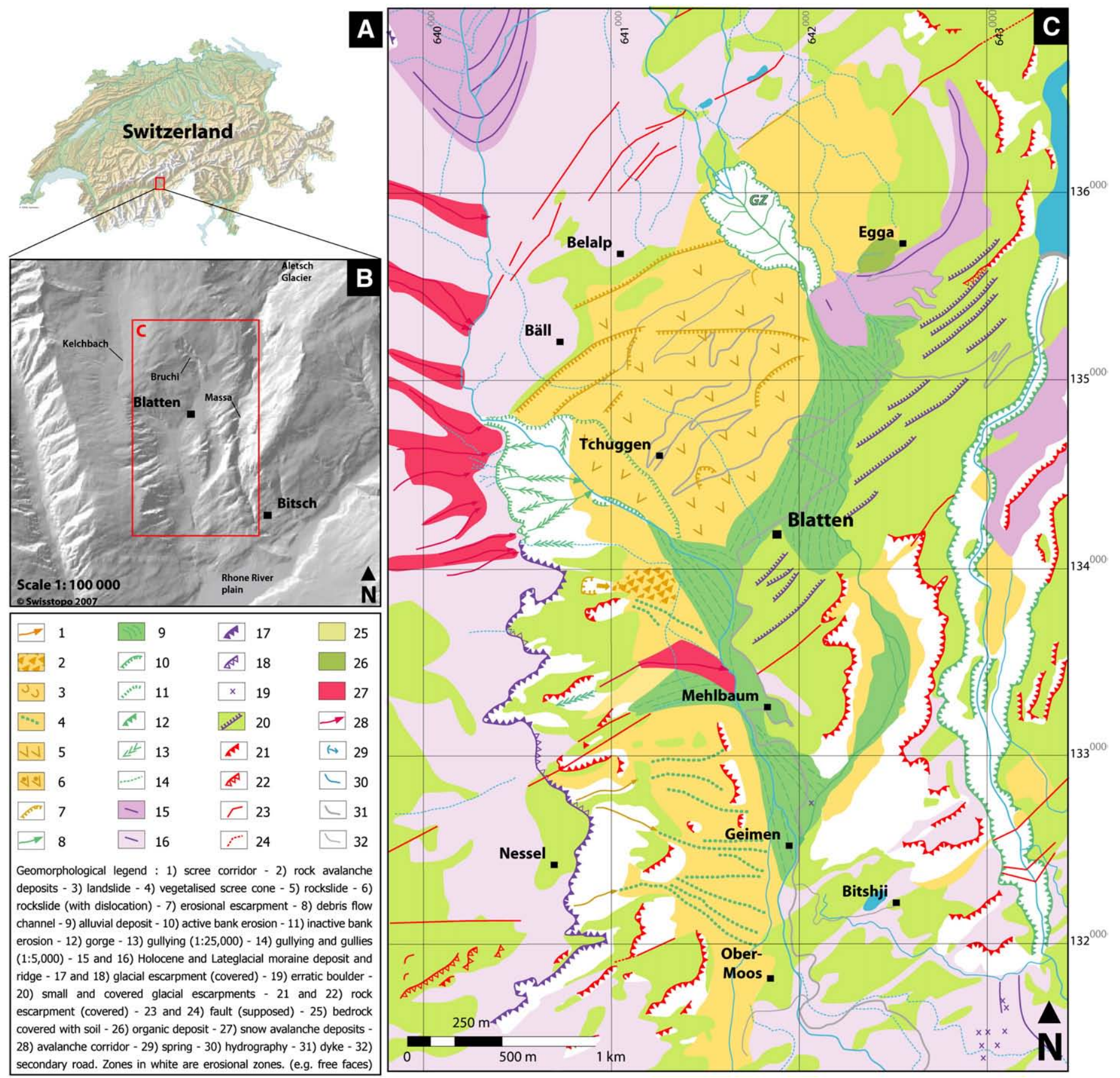

Fig. 3. Location of the Bruchi torrent (A and B) and excerpt of the geomorphological map (C). Limits of the mapped area (C) are indicated with a red rectangle on map B.

the field. The high hierarchy of the gully network, the steep slopes and the scarce vegetation cover reveal that these units are very active sediment supply zones. They produce heterometric material coming from temporary talus slopes, rockslides and moraine deposits. This sector corresponds to the triggering zone of most debris-flow events due to the convergence of runoff coming from the cliffs and water emerging at springs.

The final map (Fig. 5, on right) illustrates the application of the methodology in the Bruchi torrent. Colours that depict morphogenesis - fluvial (alluvial deposits, natural levees) in green, gravitational (landslides, scree accumulations) in beige, structural (rocks escarpments) in red and glacial (moraine deposits) in violet - of the sediment storages correspond to those in Fig. 3. The variable intensity of the colour (shading) was used to depict the morphodynamics and, more specifically, the relative role of the storage in the global sediment dynamics of the sub-watershed. Surfaces hatched in white and black have no influence in the sediment dynamics of the torrential system (Fig. 2).

The map illustrates the spatial distribution of active sediment storages in the supply zone, its geomorphological behaviour and the type of deposits that could be eroded during a pluviometric event (Fig. 5). This map is more precise and comprehensive than the map on the left, produced with a classical "IGUL" geomorphological mapping system.

\subsubsection{Field measurements}

In addition to aerial photograph interpretation and DEM analysis, thorough field geomorphological mapping coupled with complementary 

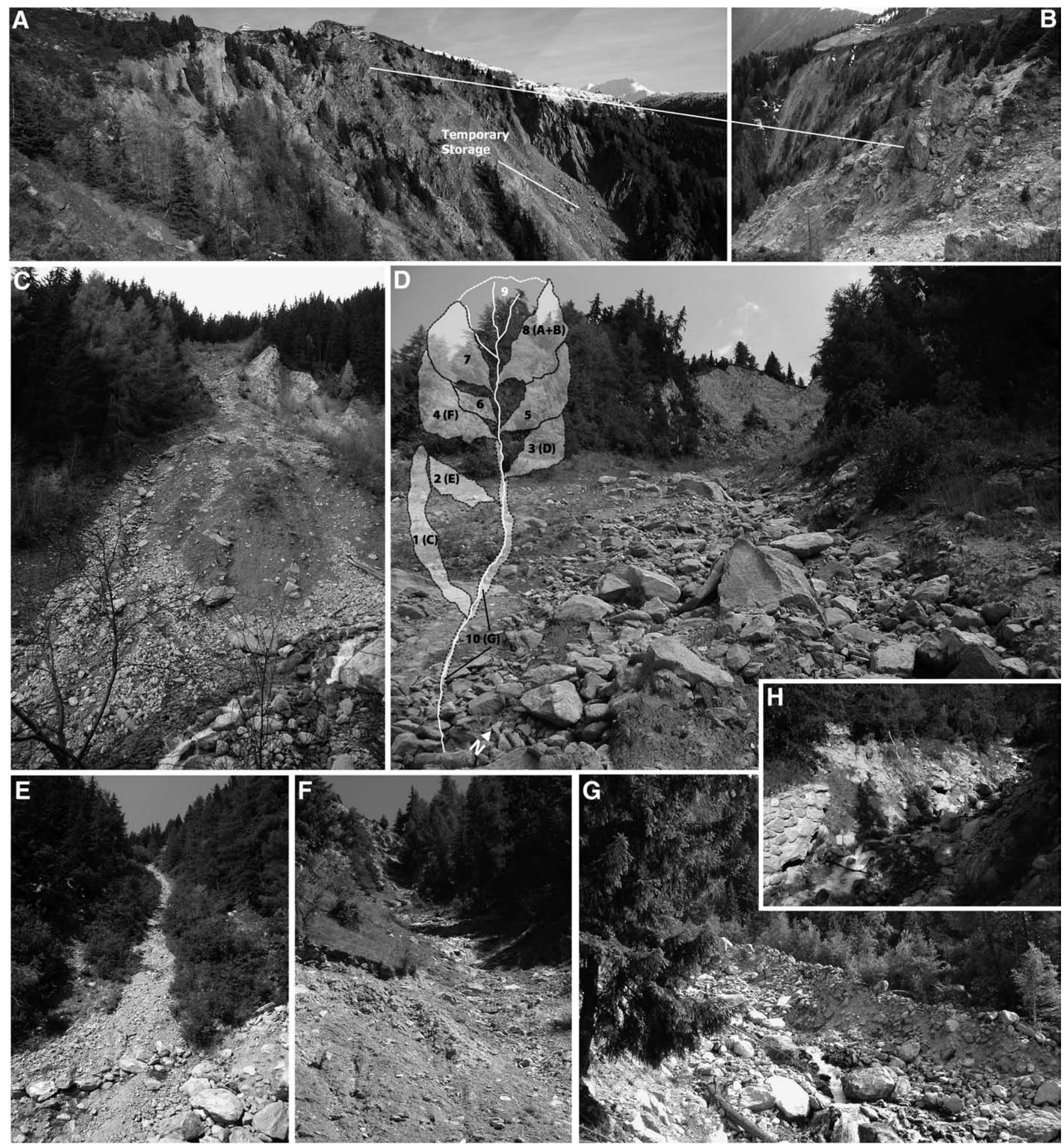

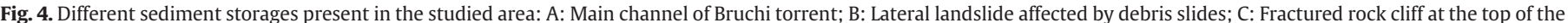

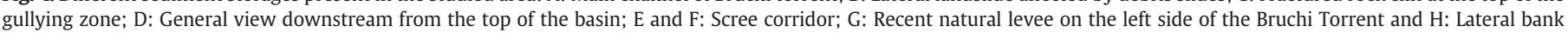
erosion/collapse (Pictures: April and July 2007). Superimposed map on picture D showing the location of these 10 storages connected to the main channel.

measurements was conducted to estimate sediment fluxes and denudation rates, using various methods (reference coloured lines, wooden markers and terrestrial LiDAR) proposed for debris-flow prospection (e.g. Delannoy and Rovera, 1996; Schrott et al. 2003; Otto and Dikau, 2004; Krautblatter and Dikau, 2007). Reference coloured lines and wooden markers were installed in July 2007 respectively in three lateral channels and on two landslides to check the existence of transfer processes. The sites were checked twice a year between Summer 2007 and Autumn 2009. Such measurements cover a short period but are in agreement with the results of geomorphological mapping. In some places (e.g. unit 2, Fig. 4), no signs of displacement of coarse elements were detected during one year. In units 1 and 3 , reference lines revealed that in the two cases, the channel was activated in most pluviometric events. In November 2007, the majority of the wooden markers were destroyed by mass wasting.

Terrestrial LiDar scanning was also used in two places. Three field campaigns were carried out at the top of the gullying zone in June 2008, November 2008 and August 2009. Two campaigns were also 


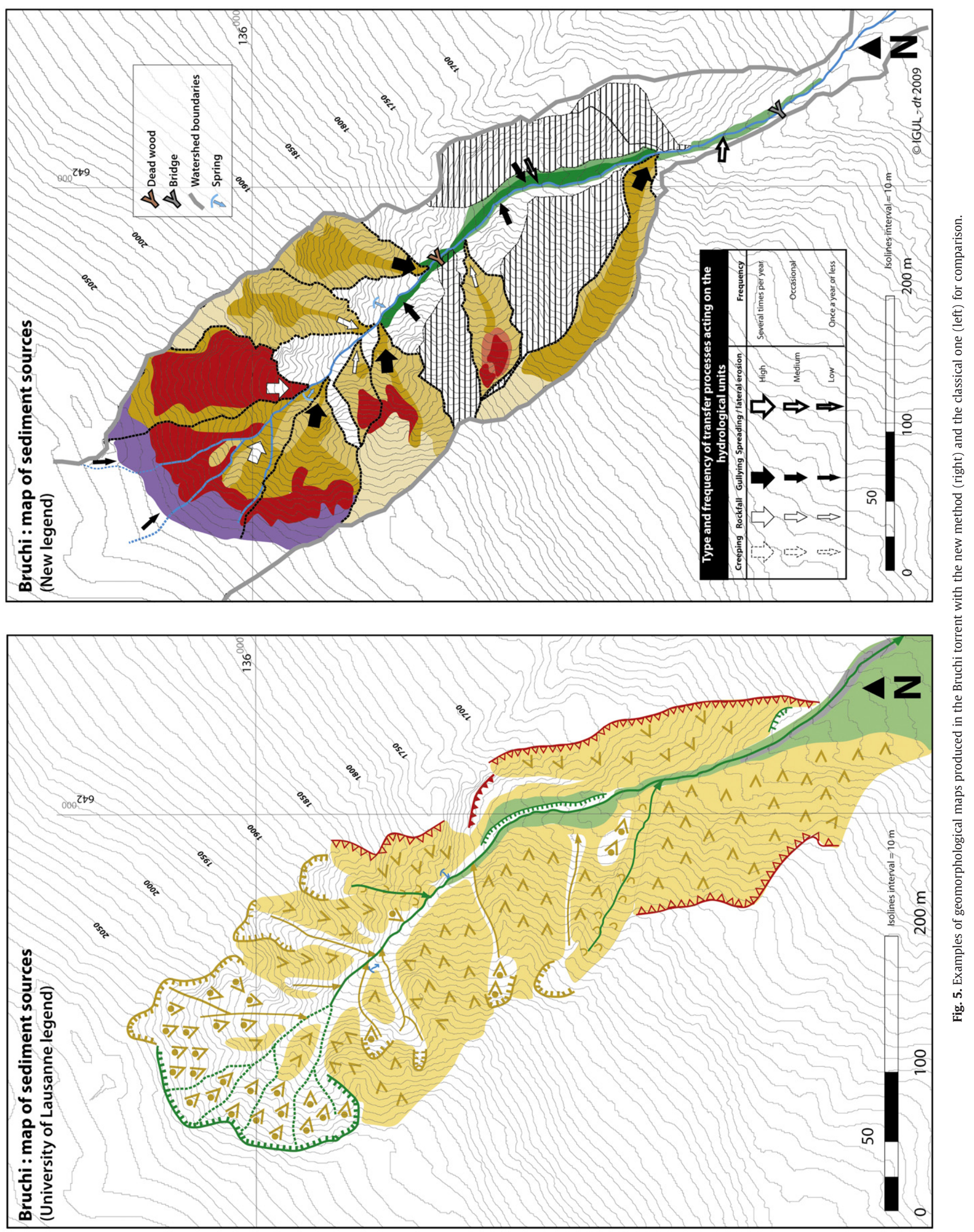


conducted in two different sediment stores (lateral levee, unit 10 and landslide, unit 1, Fig. 4) in August 2008 and 2009. Preliminary results obtained for unit 8 confirm the intensive erosion of the area and show that between June and November 2008 a localised rockslide of several tens of cubic meters occurred and reached the main channel.

In our opinion these measurements have a high representativeness as we consider that the interannual variability in sediment supply for this catchment is low. Sediment supply varies in the different seasons. Gelifraction is pronounced during spring and autumn and feed temporary deposition zones through scree accumulations while snow avalanches are mainly active during spring in some corridors where clasts and wood are transported. The purging of the higher gullies by runoff - which can trigger small shallow landslides - called a "fire hose effect" (Coe et al., 1997), mainly occurs during summer storms. Nonetheless, connectivity should be checked after each torrential event. Impacts of a landslide directly connected to the main channel could be the mobilisation of part of the sediment store, the acceleration of sediment transfer through basal undercutting, or the modification of the connectivity of the lateral channels with the main one because of the accumulation of sediments in the main channel.

\section{Discussion}

\subsection{Advantages of the method}

The method proposed here integrates field observations, aerial photographs interpretation and GIS processing. With respect to classical geomorphological mapping it is focused on the delineation and characterisation of the sediment storages that have the potential to contribute material to future debris-flow events. It is a processoriented cartographic method, whereas most geomorphological mapping systems developed in the past were much more based on landform-oriented legends aiming at classifying the landforms according to their genesis and relative chronology. Nevertheless, the proposed approach does not completely abandon the genetic approach as it classifies the sediment storages according to the genetic processes. One improvement is the use of colour intensities (shading) for representing the susceptibility of sediment storages to reach the main channel. In this sense, the proposed methodology tries to combine morphogenetic and morphodynamic information. The final aim is to give a preliminary semi-quantitative evaluation of the sediment that can be potentially mobilised by a hydro-meteorological event (Fig. 5).

The second advantage of the method is that it implements the sediment cascade concept in a cartographic system. Not only the different interconnected sediment reservoirs are defined but they are also mapped, with an indication of the genetic type of deposits. These maps provide a better understanding of the spatial relationships of the sediment reservoirs at different scales.

The use of GIS hydrographic tools allows a quick delineation of the different subcatchments corresponding to units in the map. The combination of two of the key factors - slope gradient and vegetation cover - superposed on the map of deposits - allows us to identify the areas most susceptible to erosional processes. The second matrix that combines the connectivity and the degree of activity of geomorphological processes aims at delineating the parts of the sediment storages that are susceptible to contribute to the sediment transfer during an event.

\subsection{Limitations of the method and perspectives}

The presented mapping method can be considered as an interesting tool for a preliminary analysis of a torrential system where the main sediment supply zones are morphologically well defined. Nevertheless, the method is still not sufficient to quantify the volumes that could be mobilised during a sediment transfer event. Based only on field observations and topographic data processing, the results remain semi-quantitative for the moment. They give more of a cartographic view of the spatial distribution of the different types of sediment stores in the supply zone that could be potentially eroded during a pluviometric event. The temporal validity of these documents is limited due to the highly dynamic nature of such environments. Moreover, the frequency of the processes involved in the deposition of sediments in the main channel is also approached in a qualitative way based essentially on simple field measurements. This is the reason why the cartographic information must be completed by field measurements carried out in the most sensitive areas defined by the mapping method and why the data have to be re-measured after each geomorphologic disturbance event, such as a debris flow.

At the moment, the proposed method does not take into account the secondary repositories and considers only the original supply process and the connection between the several stores within a hydro-geomorphological unit. Although sediment transfer starts generally from the hill slopes - where physical weathering followed by gravitational processes are predominant - the time of residence of sediments in the upper catchment is very variable depending on the topographic setting and the intensity of processes (Smith and Dragovich, 2008). Moreover, in drainage basins sediments may often have a second repository when they reach the main active channel where the time of residence largely depends on water runoff. Indeed, the sediment transfer from the upper part of the catchment to the alluvial fan is a very discontinuous process, characterised by long periods of quiescence separated by short intense hydrological events (Blair and McPherson, 1994) with high geomorphic effectiveness. It has been argued that the main channel can supply 70 to $100 \%$ of the sediments transported during an event (Gutiérrez et al., 1998; Johnson and Warburton, 2002; Veyrat-Charvillon, 2005).

The next steps of this approach will be to distinguish the various types of deposits in a cartographic manner. Sedimentary transfers will be quantitatively estimated based on already published values (e.g. Curry et al., 2006; De Vente and Poesen, 2005; Matsuoka, 2008) and terrestrial surveys carried out with terrestrial LiDAR. In fact, the case study showed that the sediment transfer evaluation should be, when possible, validated by field survey. In watersheds affected by mass wasting, terrestrial survey (LiDar, differential GPS) and remote sensing methods may be used and their results can be confronted with the cartographic results.

In this study the lithological information was deliberately not taken into account because the Bruchi area is composed of only one rock type; highly fractured gneisses. The second reason was to avoid the excess of information on the map to make it readable. Nevertheless, the total amount of material furnished by the source area may be very different depending on the bedrock lithology. Some materials (e.g. loess, alluvial deposits, clays etc.) are very sensitive to erosion. Investigations on the way of including lithological information in the procedure will be carried out in the future. Finally, the type of vegetation (parameters as root depths, weight on the slope) should be taken into account in some cases.

\section{Conclusions}

The aim of this study was to improve the traditional genetic-based geomorphological mapping method by developing an approach with a higher utility for the study of geomorphological hazards like debris flows. The scope was reached by developing a field mapping with GIS hydro-topographical processing. A novel methodology consisting of six steps is proposed. Most of them are developed by GIS processing on high-resolution DEM. The whole source area (reception basin) of a torrential system is divided - by using the hydrological tools of a GIS software - into several hydro-geomorphological units (subcatchments). In each unit the sediment stores are mapped by using a 
morphogenetic legend. Each unit is then divided into subunits by using two matrixes that combine slope gradient and vegetation cover (matrix 1) and connectivity with the main channel and type of store (matrix 2). This step allows the subcatchments that contribute sediment to the main channel to be determined. These are the geomorphological units where further field investigations can be carried out in order to determine their contribution to the sediment transferred during a hydro-geomorphological event.

The interest of this mapping method is that it allows the concept of sediment cascade to be spatially implemented. By allowing the various sediment storages and their relationships to be viewed on a map it can be used for hydro-geomorphological hazard mitigation. The map cannot be used directly for the creation of hazard or risk maps, focused on the deposition areas, but for the design of correction measures and the implementation of monitoring and warning systems (e.g. Hegg et al., 2007).

\section{Acknowledgements}

This study was supported by the Canton of Valais-Forest and Landscape Service (coordinator: Charly Wuilloud), and the Road and Watercourse Service (coordinators: Dominique Bérod and Eric Vez). For field and methodological support in LiDAR use, we would like to thank Andrea Pedrazzini, Thierry Oppikoffer, Alexandre Loye and Michel Jaboyedoff (IGAR) and Stéphanie Jaquet (IGUL). We also thank Simon Martin for support in using ArcGIS tools. The English proofreading by Meredith Blake was much appreciated, as well as suggestions proposed by two anonymous reviewers and Francisco Guttiérez.

\section{References}

Bardou, E., 2002. Méthodologie de diagnostic des laves torrentielles sur un bassin versant alpin. Ph.D. Thesis (2479), EPFL, Lausanne, Switzerland.

Bardou, E., Boivin, P., Pfeiffer, H.-R., 2007. Properties of debris flow deposits and source materials compared: implications for debris flow characterization. Sedimentology $54,1-12$.

Barsch, D., Caine, N., 1984. The nature of mountain geomorphology. Mountain Research and Development 4, 287-298.

Bartsch, A., Gude, M., Gurney, S.D., 2009. Quantifying sediment transport processes in periglacial mountain environments at a catchment scale using geomorphic process units. Geografiska Annaler 91A, 1-9.

Becht, M., Haas, F., Heckmann, T., Wichmann, V., 2005. Investigating sediment cascades using field measurements and spatial modelling. Proceedings of symposium held during the Seventh IAHS Scientific Assembly at Foz do Iguaçu, Brazil, April 2005, 206-213.

Beylich, A.A., Warburton, J., 2007. Analysis of source-to-sink-fluxes and sediment budgets in changing high-latitude and high-altitude cold environments. SEDIFLUX Manual. First Edition. NGU Report 2007.053.

Blair, T.C., McPherson, J.G., 1994. Alluvial fans and their natural distinction from rivers based on morphology, hydraulic processes, sedimentary process, and facies assemblages. Journal of Sedimentary Research A64, 450-489.

Bollschweiler, M., 2003. Frequenzanalyse von Murgangereignissen anhand dendrogeomorphologischer Untersuchungen. Murkegel Bruchji, Blatten b. Naters, Wallis, Schweiz. Diploma thesis, University of Fribourg.

Bollschweiler, M., Stoffel, M., Ehmisch, M., Monbaron, M., 2007. Reconstructing spatiotemporal patterns of debris-flow activity using dendrogeomorphological methods. Geomorphology 87, 337-351.

Bonnet-Staub, I., 2001. Une méthodologie d'analyse et de cartographie de l'aléa «initiation de laves torrentielles»- Application au torrent du Bragousse (France). Bull. Eng. Geol. Env. 59, 319-327.

Borselli, L., Cassi, P., Torri, D., 2008. Prolegomena to sediment and flow connectivity in the landscape: a GIS and field numerical assessment. Catena 75, 268-277.

Bovis, M.J., Jakob, M., 1999. The role of debris supply conditions in predicting debris flow activity. Earth Surface Processes and Landforms 24, 1039-1054.

Cannon, S.H., Reneau, S.L., 2000. Conditions for generation of fire-related debris flows, Capulin Canyon. New Mexico. Earth Surf. Process. Landforms 25, 1103-1121.

Carrara, A., Crosta, G., Frattini, P., 2008. Comparing models of debris-flow susceptibility in the alpine environment. Geomorphology 94, 353-378.

Coe, J.A., Glancy, P.A., Whitney, J.W., 1997. Volumetric analysis and hydrologic characterization of a modern debris flow near Yucca Mountain Nevada. Geomorphology 20,11-28.

Croke, J., Mockler, S., Fogarty, P., Takken, I., 2005. Sediment concentration changes in runoff pathways from a forest road network and the resultant spatial pattern of catchment connectivity. Geomorphology 68, 257-268.
Curry, A.M., Cleasby, V., Zukowsky, P., 2006. Paraglacial response of steep, sedimentmantled slopes to post-“Little Ice Age" glacier recession in the central Swiss Alps. Journal of Quaternary Science 21, 211-225.

De Vente, J., Poesen, J., 2005. Predicting soil erosion and sediment yield at the basin scale: scale issues and semi-quantitative models. Earth Science Reviews 71, 95-125.

Delannoy, J.-J., Rovera, G., 1996. L'érosion dans les Alpes occidentales: contribution à un bilan des mesures et des méthodes. Rev. Geo. Alp. 87-101 1996/2.

Fall, M., Azzam, R., Noubactep, C., 2006. A multi-method approach to study the stability of natural slopes and landslide susceptibility mapping. Engineering Geology 82 241-263.

Gabbet, E.J., Mudd, S.M., 2006. The mobilization of debris flows from shallow landslides. Geomorphology 74, 207-218.

Gachet, G., 2009. Analyse et exploitation des données de LiDAR aéroportés pour la caractérisation des milieux boisés de Suisse. Ph.D. Thesis (4283), EPFL, Lausanne Switzerland.

Greenway, D.R., 1987. Vegetation and slope stability. In: Anderson, M.G., Richards, K.S (Eds.), Slope Stability. Wiley, Chichester, pp. 187-230.

Gustavsson, M., Kolstrup, E., Seijmonsbergen, A.C., 2006. A new symbol-and-GIS based detailed geomorphological mapping system: renewal of a scientific discipline for understanding landscape development. Geomorphology 77, 90-111.

Gustavsson, M., Seijmonsbergen, A.C., Kolstrup, E., 2008. Structure and contents of a new geomorphological GIS database linked to a geomorphological map-with an example from Liden, central Sweden. Geomorphology 95, 335-349.

Gutiérrez, F., Gutiérrez, M., Sancho, C., 1998. Geomorphological and sedimentological analysis of a catastrophic flash flood in the Aràs drainage basin (Central Pyrennes, Spain). Geomorphology 22, 265-283.

Heckmann, T., Thiel, M., Haas, F., Becht, M., 2009. Towards a quantification of sedimentary connectivity in a Central Alpine catchment. Geophysical Research Abstracts 11 EGU2009-9129.

Hegg, C., Romang, H., Dufour, F., Hilker, N., Zappa, M., Rhyner, J., 2007. IFKIS-Hydro-a flood hazard information and warning system for smaller catchments. $29^{\text {th }}$ International Conference on Alpine Meteorology, Chambéry, 4-8 June 2007. Extended Abstract, $4 \mathrm{p}$.

Hooke, J., 2003. Coarse sediment connectivity in river channel systems: a conceptual framework and methodology. Geomorphology 56, 79-94.

Hungr, O., McDougall, S., Wise, M., Cullen, M., 2008. Magnitude-frequency relationships of debris flows and debris avalanches in relation to slope relief. Geomorphology 96 , 335-365.

Johnson, R.M., Warburton, J., 2002. Annual sediment budget of a UK mountain torrent Geogr. Ann. 84A, 73-88

Johnson, R.M., Warburton, J., 2006. Variability in sediment supply, transfer and deposition in an upland torrent system: Iron Crag, northern England. Earth Surf. Process. Landforms 31, 844-861.

Joly, F.-M., 1962. Principes pour une méthode de cartographie géomorphologique. Bull. Ass. Géogr. Franç. 309/310, 271-277.

Kamp, U., Growley, B.J., Khattak, G.A., Owen, L.A., 2008. GIS-based landslide susceptibility mapping for the 2005 Kashmir earthquake region. Geomorphology 101, 631-642.

Kienholz, H., 1978. Maps of Geomorphology and Natural Hazards of Grindelwald, Switzerland: Scale 1: 10 000. Arctic and Alpine Research 10 (2), 168-184.

Kienholz, H., Krummenacher, B., 1995. Légende modulable pour la cartographie des phénomènes. Recommandations, Dangers naturels, OFEFP et OFEE, Berne. 19 p.

Klimaszewski, M., 1982. Detailed geomorphological maps. ITC Journal 3, 265-271.

Kneisel, C., Rothenbühler, C., Keller, F., Haeberli, W., 2007. Hazard assessment of potential periglacial debris flows based on GIS-based spatial modelling and geophysical field survey: A case study in the Swiss Alps. Permafrost and Periglacial Processes 18, 259-268.

Korup, O., 2004. Landslide-induced river channel avulsions in mountain catchments of southwest New Zealand. Geomorphology 63, 57-80.

Krautblatter, M., Dikau, R., 2007. Towards a uniform concept for the comparison and extrapolation of rockwall retreat and rockfall supply. Geogr. Ann. 89A, 21-40.

Latulippe, C., Peiry, J.-L., 1996. Essai de hiérarchisation des zones de production de matières en suspension dans le bassin versant d'un grand cours d'eau: l'Isère en amont de Grenoble. Rev. Geo. Alp. 2, 29-44.

Lee, E.M., 2001. Geomorphological mapping. In: Griffiths, J.S. (Ed.), Land Surface Evaluation for Engineering Practice. : Engineering Geology Special Publications, 18. Geological Society, London, pp. 53-56.

Malet, J.-P., Laigle, D., Remaître, A., Maquaire, O., 2005. Triggering conditions and mobility of debris flows associated to complex earthflows. Geomorphology 66, 215-235.

Maridet, L., Piégay, H., Gilard, O., Thevenet, A., 1996. L'embâcle de bois en rivière: un bienfait écologique ? Un facteur de risques naturels ? La Houille Blanche 5, 32-38.

Marie, R., 1992. Typologie des situations de danger. Unpublished report, CEMAGREF, Grenoble, France.

Mark, D.M., 1984. Automated detection of drainage networks from digital elevation models. Cartographica 21, 168-178.

Mathys, N., Poesen, J., 2005. Ravinement en montagne: processus, mesures, modélisation, régionalisation. Géomorphologie: Relief, Processus, Environnement 1/2005, 3-6.

Matsuoka, N., 2008. Frost weathering and rockwall erosion in the southeastern Swiss Alps: long-term (1994-2006) observations. Geomorphology 99, 353-368.

May, J.-H., 2008. A geomorphological map of the Quebrada de Purmamarca, Jujuy, NW Argentina. Journal of Maps 211-224.

Mc Ivor, J.G., Williams, J., Gardener, C.J., 1995. Pasture management influences runoff and soil movement in the semi-arids tropics. Australian Journal of Experimental Agriculture 35, 55-65.

Michaelides, K., Chappell, A., 2008. Connectivity as a concept for characterising hydrological behaviour. Hydrological Processes 23, 517-522. 
Moreias, S.M., 2005. Landslide susceptibility zonation in the Rio Mendoza Valley, Argentina. Geomorphology 66, 345-357.

OFAT, OFEE, OFEFP, 1997. Prise en compte des dangers dus aux crues dans le cadre des activités de l'aménagement du territoire. Recommandations 1997, Dangers naturels, Berne, $32 \mathrm{p}$.

Otto, J.-C. 2006. Paraglacial sediment storage quantification in the Turtmann Valley, Swiss Alps. Ph.D Thesis, Rheinischen Friedrich-Wilhelms-Universität Bonn, Germany.

Otto, J.-C., Dikau, R., 2004. Geomorphologic system analysis of a high mountain valley in the Swiss Alps. Z. Geomorph. N.F. 48, 323-341.

Parise, M., 2001. Landslide mapping techniques and their use in the assessment of the landslide hazard. Phys. Chem. Earth 26, 697-703.

Pasuto, A., Soldati, M., 1999. The use of landslide units in geomorphological mapping: an example in the Italian Dolomites. Geomorphology 30, 53-64.

Reid, L.M., Dunne, T., 1996. Rapid Evaluation of Sediment Budgets. Catena Verlag. 164 pp.

Rey, F., Ballais, J.-L., Marre, A., Rovéra, G., 2004. Rôle de la végétation dans la protection contre l'érosion hydrique de surface. Comptes Rendus Géoscience 336 (1), 991-998.

Rickenmann, D., 1995. Beurteilung von Murgängen. Schweiz. Ing. Archit. 113 (48), 1104-1108.

Rogers, R.D., Schumm, S.A., 1991. The effect of sparse vegetative cover on erosion and sediment yield. Journal of Hydrology 123, 19-24.

Sanchez, M.J., 2002. Slope deposits in the Upper Nalòn River Basin (NW Spain): an approach to a quantitative comparison. Geomorphology 43, 165-178.

Schoeneich, P., 1993. Comparaison des systèmes de légendes français, allemand et suisse - principes de la légende IGUL. In: Schoeneich, P., Reynard, E. (Eds.) Cartographie géomorphologique, cartographie des risques. Institut de Géographie, Université de Lausanne, Travaux et. Recherches 9, 15-24.

Schrott, L., Niederheide, A., Hankammer, M., Hurfschmidt, G., Dikau, R., 2002. Sediment storage in a mountain catchment: geomorphic coupling and temporal variability (Reintal, Bavarian Alps, Germany). Z. Geomorph. N.F. 127, 175-196.

Schrott, L., Hufschmidt, G., Hankammer, M., Hoffmann, T., Dikau, R., 2003. Spatia distribution of sediment storage types and quantification of valley fill deposits in an alpine basin, Reintal, Bavarian Alps, Germany. Geomorphology 55, 45-63.

Schuerch, P., Densmore, A.L., McArdell, B.W., Molnar, P., 2006. The influence of landsliding on sediment supply and channel change in a steep mountain catchment. Geomorphology 78, 222-235.

Sitar, N., 1994. Initiation of rainfall-induced debris flows. In: Sociedad Ecuatoriana de mecanica de suelos y rocas (Editor), First Panamerican symposium on landslides, Gayaquil, pp. 23-35.)

Smith, H.G., Dragovich, D., 2008. Sediment budget analysis of slope-channel coupling and in-channel sediment storage in an upland catchment, southeastern Australia. Geomorphology 101, 643-654.
Steck, A., 1966. Petrographische und tektonische Untersuchungen am Zentralen Aaregranit und seinen altkristallinen Hüllgesteinen im westlichen Aarmassiv im Gebiet Belalp-Grisgighorn. Beitrage zur Geologischen Karte der Schweiz, Stämpfli, Bern.

Sterling, S., Slaymaker, O., 2007. Lithologic control of debris torrent occurrence. Geomorphology 86, 307-319.

Stiny, J., 1910. Die Mure. reprint University of Innsbruck, Innsbruck.

Swisstopo, 2007. Géodonnées. Geodata-news 14.

Theler, D., Reynard, E., 2008. Mapping sediment transfer processes using GIS applications. Proceedings $6^{\text {th }}$ ICA Mountain Cartography Workshop, Lenk, Switzerland, pp. 227-234.

Theler, D., Reynard, E., Bardou, E., 2007. From geomorphological mapping to risk assessment: a project of integrated GIS application in the western Swiss Alps. Proceedings of the 5th Mountain Cartography, Bohinj, Slovenia, pp. 236-241.

Theler, D., Reynard, E., Bardou, E., 2008. Assessing sediment dynamics from geomorphological maps: Bruchi torrential system, Swiss Alps. Journal of Maps 2008, 277-289.

Tricart, J., 1971. Les études géomorphologiques pour la conservation des terres et des eaux. Options Méditerranéennes 9, 94-99.

Van Asselen, S., Seijmonsbergen, A.C., 2006. Expert-driven semi-automated geomorphological mapping for a mountainous area using a laser DTM. Geomorphology 78, 309-320.

Van Den Eeckhaut, M., Poesen, J., Verstraeten, G., Vanacker, V., Moeyersons, J., Nyssen, J., van Beek, L.P.H., 2004. The effectiveness of hillshade maps and expert knowledge in mapping old deep-seated landslides. Geomorphology 67, 351-363.

Veyrat-Charvillon, S., 2005. Elaboration d'une méthode de prédiction du volume maximal d'une lave torrentielle. Topographie de terrain et Stéréophotarammétrie sur photographies aériennes d'archives. Torrents du Manival, du Merdarêt et des Archess (Alpes-du-Nord, Isère, France). Ph.D Thesis, Université Blaise Pascal, Clermont-Ferrand 2, France.

Veyrat-Charvillon, S., Mémier, M., 2006. Stereophotogrammetry with a topographic methodology of debris flow torrent measurements: calculation of channel sediment states and partial sediment budget on Manival torrent (Isère, France). Earth Surface Processes and Landforms 31 (2), 201-219.

Vitek, J.D., Giardino, J.R., Fitzgerald, J.W., 1996. Mapping geomorphology: a journey from paper maps, through computer mapping to GIS and Virtual Reality. Geomorphology 16, 233-249.

Vogt, J.V., Colombo, R., Bertolo, F., 2003. Deriving drainage networks and catchment boundaries: a new methodology combining digital elevation data and environmental characteristics. Geomorphology 53, 281-298.

Zimmermann, M., Mani, P., Romang, H., 1997. Magnitude-frequency aspects of alpine debris flows. Eclogae geol. Helv. 90, 415-420. 